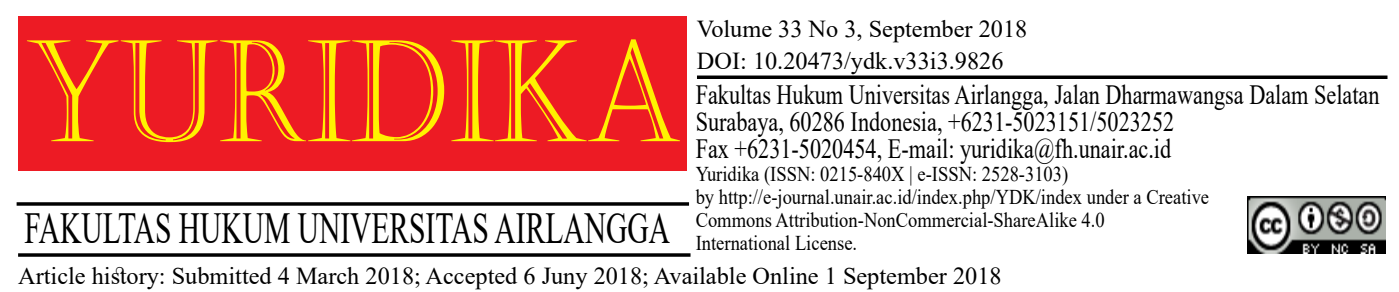

\title{
Compulsory Vaccination for Children in Malaysia: Legislation and Realisation
}

\author{
Nurul Jannah binti Mustafa Khan and Zuhaira Nadiah binti Zulkipli \\ nuruljannah5546@salam.uitm.edu.my \\ Universiti Teknologi MARA Malaysia
}

\begin{abstract}
For ages, it has been proven that vaccines are among the most effective tools in preventing infectious diseases from spreading in the population of human beings. The result of high immunization coverage is the drastic deteriorations in vaccinepreventable diseases. Hence, it is indeed disturbing to see the report by Ministry of Health that the number of cases of parents refusing vaccination for their children is escalating, for an example, measles and pertussis cases to rise. Whether these parents realized it or not, they had denied the right of their children to be vaccinated against preventable diseases that had been in control all this while because of vaccines, and more, jeopardizing the public health as well. For this reason, the Ministry of Health has contemplated making vaccination compulsory for children as to protect them against preventable diseases and for the benefit of the society as a whole. This article discusses the extent of the regulations that may be implemented. Therefore for the purpose of this article, the scrutinization of vaccination law as implemented in California will be referred. At the end of this article, some recommendations are proposed in relation to the realization of legislation of vaccination regulations that may be implemented by the government, hopefully soon. This article employs a doctrinal analysis and secondary data from academic journals and online databases. Keywords: Compulsory Vaccination; Immunization; Malaysia; Regulations; VaccinePreventable Diseases.
\end{abstract}




\section{Introduction}

It is disturbing to see the report by Ministry of Health of Malaysia that the number of cases of parents refusing vaccination for their children is escalating. ${ }^{1}$ This refusal of vaccination has caused measles and diphtheria cases to rise. ${ }^{2}$ Vaccination is crucial for children as they stimulate the immune system to produce antibodies for specific diseases, thus strengthening the immune system because the defence cells now can recognize these specific diseases and can fight against them better. ${ }^{3}$ According to the Johor Health, Environment, Education and Information Committee Chairman, Ayub Rahman, a number of diseases such as tuberculosis had been on the rise as the result of no vaccination administered since birth. ${ }^{4}$ These parents need to realise that they had denied the right of their children to be vaccinated against preventable undesired diseases particularly such as measles and pertussis that had been in control all this while due to prevention made through vaccination. These parents vehemently upholding their choice by rejecting vaccination for their children on the ground that they had done their own personal research and claimed that amongst other reasons, vaccines contained pig DNA thus claiming that vaccines fall under the category of non-permissible practices in the eyes of Islam which and may cause autism to their children despite numerous explanations given by Ministry of Health. For this reason, the Ministry of Health has decided to make vaccination compulsory for children as to protect them against preventable diseases

${ }^{1}$ Outbreak News Today, 'Malaysia: Diphtheria, Measles and Vaccination Rejection' (Outbreak News Today, 2018) <http://outbreaknewstoday.com/malaysia-diphtheria-measles-andvaccination-rejection-52840/> accessed 20 June 2017.

${ }^{2}$ ibid.

${ }^{3}$ Moh.gov.my., 'Official Portal for Ministry of Health MalaysiaFrequently Asked Questions' (Moh.gov.my., 2018) <http://www.moh.gov.my/english.php/pages/view/160> accessed 25 July 2018."7”, “25”] ] \}, "author” : [ \{ "dropping-particle” : “", "family” : “Moh.gov.my.”, "given” : “”, "non-dropping-particle" : “", "parse-names" : false, "suffix" : "” \} ], "container-title” : "Moh.gov. my.", "id" : "ITEM-1", "issued" : \{ "date-parts" : [ " $2018 ”]$ ] \}, "title" : "Official Portal for Ministry of Health MalaysiaFrequently Asked Questions", "type" : "webpage" \}, "uris" : [ "http://www. mendeley.com/documents/?uuid=73728f52-1137-40ef-add9-8bae0ada6417" ] \} ], "mendeley" : \{ "formattedCitation" : "Moh.gov.my., lu2018Official Portal for Ministry of Health MalaysiaFrequently Asked Questions $\mid u 2019(<\mathrm{i}>$ Moh.gov.my. $</ \mathrm{i}>, 2018$

${ }^{4}$ M Chow, 'Anti-Vaccine Group's Actions at "worrying Level" among Malays' (Free Malaysia Today, 2018) <http://www.freemalaysiatoday.com/category/nation/2018/03/27/antivaccine-groups-actions-at-worrying-level-among-malays/> accessed 12 July 2018. 
and for the benefit of the society as a whole. This article discusses the extent of the regulations that can be implemented and for this purpose California vaccination law is being considered together with the Islamic Legal perspective on vaccination in Malaysia. It is observed that currently discussion on prevention and termination of disease through a legal framework is lacking. Hence, it is hoped that this article will contribute to the literature review regarding prevention of communicable disease by legal framework.

\section{The Necessity for Compulsory Vaccination}

The practice of vaccination is not a new method that has only been discovered for a few years back. Vaccination has a long history back to 1774 where a cattle breeder known as Benjamin Jesty who has been infected by cowpox discovered that he was immune to the more fatal disease that is smallpox, deliberately injected his wife and two sons with cowpox. ${ }^{5}$ Not surprisingly, his actions in deliberately infecting his wife and sons by animal disease was being scorned by his neighbors. ${ }^{6}$ For that reason, Jesty has never attempted to publicize his experiment. ${ }^{7}$ However, it is truly astounding to see a regular cattle breeder, not even a scientist or a physician can see the link between immunity to smallpox to prior infection with cowpox. ${ }^{8}$

Fortunately, vaccination be made popular by a scientist known as Edward Jenner ${ }^{9}$ who inoculated an eight year old boy with cowpox and later on with fresh smallpox lesion, where he found that the boy did not develop the smallpox disease. From then on, attempts had been made by Edward Jenner in making the society believe in the findings of his experiments and observations, with difficulties at first of course. Jenner's work has been recognized as the first scientific attempt to control infectious disease by vaccination, although historically, he was not the one

\footnotetext{
${ }^{5}$ S. L. Plotkin and Stanlay A. Plotkin, 'A Short History of Vaccination' (2004) 5 Vaccines.[1-16].

${ }^{6}$ ibid.

7 ibid.

8 ibid.

9 S Riedel, 'Edward Jenner and the History of Smallpox and Vaccination' (2005) 18 Baylor University. Medical Center <https://www.ncbi.nlm.nih.gov/pubmed/16200144>.[21-25].
} 
who discovered vaccination. ${ }^{10}$ In 1977 the world has triumphed over the disease of smallpox where it has been successfully eradicated, leaving the future generation with only the remembrances of the haunting disease of the past that can cause blindness and disfigurement and even death to its victims. ${ }^{11}$ From then on, there is no turning back, the method of vaccination has changed the medicine world to the better, where among others, vaccination has helped in the near elimination of diseases such as measles, mumps and rubella. ${ }^{12}$

Now, that is the story of the past. Coming back to the modern era, where childhood vaccine preventable diseases have been effectively controlled, a large outbreak of measles started in Disneyland, California in 2014 causing alarm to the public health officials and the public simultaneously the awareness to the rise of anti-vaccination movements who has been refusing vaccination shots for their children. ${ }^{13}$ It is realized that these anti vaccination movements has started since the beginning of the use of vaccines. ${ }^{14}$ This measles outbreak has prompted the government of California to pass a new legislation concerning vaccination known as Senate Bill No.277 (SB277) that amended several sections in the Health and Safety Code particularly under the Division 105-Communicable Disease Prevention and Control, Part 2 of the Immunization ${ }^{15}$ relating to public health that has taken effect on 15 July 2016.

\section{California Vaccination Law}

In general, SB277 prohibits the governing authority of a school or other institution from admitting any person as a pupil of any public or private elementary

10 ibid.
11 ibid.
12 Y. Toni Yang,[et.,al.] 'Measles Outbreak as a Catalyst for Stricter Vaccine Exemption Legislation' (2015) 314 JAMA < https://jamanetwork.com/journals/jama/article-abstract/2417307>. [1229-1230].

${ }^{13}$ Varun K. Phadke, 'Association between Vaccine Refusal and Vaccine-Preventable Diseases in the United States: A Review of Measles and Pertussis' (2016) 315 JAMA < https://jamanetwork. com/journals/jama/article-abstract/2503179>.[1149-1158].

${ }^{14}$ G. A Poland and R. M Jacobson, 'The Clinician's Guide to the Anti-Vaccinationists' Galaxy’ (2012) 73 Human immunology.[859-866].

15 Leginfo.legislature.ca.gov, 'California Legislative Information' (Leginfo.legislature. ca.gov, 2018) <http://leginfo.legislature.ca.gov> accessed 14 November 2017. 
or secondary school, child care center, day nursery, nursery school, family day care home, or development center, unless prior to his or her admission to that institution he or she has been fully immunized against various diseases, including measles, mumps, and pertussis, subject to any specific age criteria. SB277 also necessitates the governing authority of a school or institution to require for documentary proof of immunization status of each entrant. This bill eliminates the exemption from specified immunization requirements based on personal beliefs. Before SB277 was passed, children are still permitted to be send to school despite not being vaccinated on the ground of personal beliefs exemption. ${ }^{16}$ Previously, parents are only required to sign a form expressing refusal to vaccination based on undefined personal beliefs. ${ }^{17}$ SB277 also prohibits a governing authority from admitting to any of those institutions for the first time or admitting or advancing any pupil to the 7th grade level, unless the pupil has been immunized as required by the bill.

Section 120325 of Chapter 35 Health and Safety Code highlights that it is the intent of the Legislature to provide for a means for the eventual achievement of total immunization of appropriate age groups against childhood diseases such as, diphtheria, hepatitis B, measles, mumps, rubella, pertussis and tetanus. ${ }^{18}$ The significance of this intention by the Californian government is clear as that the act of immunizing one child can lead to a protection of a group of children and in the long run, the whole country will be protected against vaccine preventable diseases. ${ }^{19}$ Section 120335 emphasizes that the governing authority shall not admit any child as a pupil of any private or public elementary or secondary school, child care center, day nursery, nursery school, family day care home, or development center, unless, he or she has been fully immunized against diphtheria, haemophilus influenzae type $b$, measles, mumps, pertussis, poliomyelitis, rubella, tetanus, hepatitis B,

\footnotetext{
${ }^{16}$ Dorit Rubinstein Reiss, 'Vaccines, School Mandates, and California's Right to Education' (2015) 63 UCLA Law Review Discourse.[98].

17 ibid.

18 ibid.[15].

19 Jenifer Ehreth, 'The Global Value of Vaccination' (2003) 21 Vaccines <https://www.researchgate.net/publication/10948246_The_global_value_of_vaccination>.[596-600].
} 
varicella (chickenpox) and any other disease deemed appropriate by the department, prior to his or her first admission to that institution, taking into consideration the recommendations of the Advisory Committee on Immunization Practices of the United States Department of Health and Human Services, the American Academy of Pediatrics, and the American Academy of Family Physicians. ${ }^{20}$

The next law relating to vaccination in the California Safety and Health Code is Section 120370 which states that children will only be admitted to school or daycare, both public and private if they are fully immunized in accordance with their age span. ${ }^{21}$ The exemption from being vaccinated should only come from a licensed physician and not from one own's belief. ${ }^{22}$ Another relevant law that can be referred in the California Health and Safety Code is Section 120375 which necessitates the governing authority, to require from each children who are about to enroll in their institution documentary proof of immunization status. ${ }^{23}$ The governing authority shall record the immunizations of each new entrant in the entrant's permanent enrollment and scholarship record on a form provided by the department. ${ }^{24}$ The process does not stop there where the immunization record of each new entrant admitted shall be reviewed periodically by the governing authority to ensure that the child has been fully immunized against all of the diseases listed in Section 120335 , and subsequent immunizations received by the entrant will be added to the immunization record. ${ }^{25}$

Section 120370 emphasizes the seriousness of the California government to curb the issue of parents' rejecting vaccination for their children where this section requires the governing authority of each school or institution to prohibit any admission by an entrant who is not fully immunized against diseases listed under the Code within the specified time given, unless the child has been exempted from

\footnotetext{
${ }^{20}$ Dorit Rubinstein Reiss (n 16).Op.Cit.

${ }^{21}$ ibid.

22 ibid.

23 ibid.

${ }^{24}$ ibid.

25 ibid.
} 
immunization under section $120370 .{ }^{26}$ From these provisions mentioned above, it may be concluded that a child who has not been fully immunized in accordance of his age span will be denied the access to be admitted to any private or public elementary or secondary school, child care center, day nursery, nursery school, family day care home, or development center. Hence, other option for these reluctant parents will be to have their children home schooled. ${ }^{27}$

\section{Children Vaccination in Malaysia}

Vaccines are safe to be used for babies and very young children. This is proven because before vaccines are marketed commercially, they are rigorously tested in large clinical trials which are strictly monitored for safety. ${ }^{28}$ The Drug Control Authority under Ministry of Health Malaysia must approve and register the vaccines before it can be used in the immunization programme in Malaysia. ${ }^{29}$ As compared to the California Law, Malaysia has no specific legislation pertaining to compulsory immunization among children. This is seen as a loophole that can be manipulated by parents in rejecting vaccination for their children. It is contended by the authors that the existence of a specific legislation relating to vaccination will make it easier for the parties relevant to take appropriate actions against parents who reject vaccinations based on unjustified reasons. As per today, the Ministry of Health only provides the vaccination schedule as a guideline for health practitioners. In 2016, the Ministry of Health has introduced the latest vaccination schedule to be adhered by physicians and parents. ${ }^{30}$ The Ministry of Health had also provides a clinical immunisation guideline namely the "Childhood Immunisation" in collaboration with Academy of Medicine on December 2004. The objective of this guideline is to aid health care providers in general practice and pediatricians in clinical decision making by

\footnotetext{
${ }^{26}$ ibid.

27 ibid.[11].

${ }^{28}$ ibid.[3].

29 ibid.

30 Kementerian Kesihatan Malaysia, 'Kementerian Kesihatan Malaysia' (Facebook.com, 2018) <https://www.facebook.com/kementeriankesihatanmalaysia/photos/a.390879946236.176260 $.373560576236 / 10153207377521237 /$ ?type=3\&theater $>$ accessed 12 March 2018.
} 
providing well balanced evidence based information on childhood immunization with the hope that this guideline can decrease the incident of complications in Malaysia. Unfortunately, this guideline had never been reviewed and updated by the Ministry of Health. ${ }^{31}$ Nevertheless, it should be noted that the Ministry of Health has taken several measures in curbing the issue of vaccinations refusal and also to strengthen the National Immunusation Program by spearheading an initiative known as National Immunisation Promotion Campaign 2016-2020.32 This campaign has specifically three objectives which are, first, to clarify rumors and allegations on vaccines safety. ${ }^{33}$ Secondly, to gain community support for the National Immunisation Program and for them to reject anti-vaccination movement. Lastly, the objective of this campaign is to promote and educate parents' on vaccination. ${ }^{34}$

Seeing that the childhood vaccination is not made compulsory in Malaysia, it leaves the options open for parents to reject vaccination for their children by filling in "Format for Vaccine Refusal" ${ }^{35}$ It is presumed that because these parents see the loopholes of children immunization programmes in Malaysia, they simply refused the right of their children to be vaccinated by giving reason such as the vaccines contains pig DNA and might cause dangerous diseases to their children. Other popular cited reason is that the vaccines may cause adverse effects, without further research and without asking the health authorities. Hence, there is a rise of numbers of parents who refused to vaccinate their children, some resorting for homeopathy treatment.

In June 2016, the decisions made by these parents has taken its toll on their own children and others when five children died from diphtheria, a disease that can

${ }^{31}$ Moh.gov.my, 'Official Portal for Ministry of Health MalaysiaPaediatric \& Child Health' (Moh. gov.my, 2018) <http://www.moh.gov.my/english.php/pages/view/218> accessed 13 November 2017.

32 Faridah Kusnin, 'Immunisation Program in Malaysia', Vaccinology 2017 III International Symposium for Asia Pacific Experts (Health Physician Disease Control Division Ministry of Health, Malaysia 2017) <https://www.fondation-merieux.org/wp-content/uploads/2017/10/vaccinology2017-faridah-kusnin.pdf $>$.

33 ibid.

34 ibid.

35 ibid. 
be prevented by vaccines. ${ }^{36}$ In August 2016, 27 cases of diphtheria are confirmed by the Health Ministry Director General, Datuk Dr Noor Hisham. ${ }^{37}$ The recent development of vaccination policy can be seen from the measure taken by the Perak Health Department who will take legal action under the Child Act 2001 against parents if their unvaccinated children contract preventable diseases. ${ }^{38}$ Besides that, there was a statement made by the then Women, Family and Community Development Ministry that indicated refusing vaccinations by parents could be made an offence under Child Act 2001. ${ }^{39}$ This measure is taken seeing that the number of parents refusing vaccination for their children has doubled compared to last year, which is definitely a disturbing trend. ${ }^{40}$ Nevertheless, it is still seen to be crucial for a specific legislation relating to vaccination to be implemented. This is because to bring an action of parents refusing vaccination under the Child Act 2001 is quite a stretch as there is no specification on vaccination refusal.

\section{Vaccination in Islamic Perspective}

Due to the non-halal issue contents in certain optional vaccine offered in Malaysia, this has cause fear to some of Muslim parents from vaccinating their children even though the ten vaccines meant for the national immunisation schedule as issued by the Ministry of Health are free from pork gelatin. ${ }^{41}$ According to the then Deputy Health Minister of Malaysia, Datuk Seri Dr. Hilmi Yahaya, there is

36 Thestar.com.my, 'Health Ministry: Five Deaths Due to Diphtheria Recorded' (The Star Online, 2018) <https:/www.thestar.com.my/news/nation/2016/06/30/health-ministry-diphtheriadeaths/> accessed 25 July 2018.

37 ibid.

38 Thestar.com.my, 'Parents of Unvaccinated Children Who Fall Ill May Be Held Responsible' (Nation The Star OnlineThe Star Online, 2018) < http://www.thestar.com.my/news/ nation/2016/08/29/perak-tackles-vaccine-issue-parents-of-unvaccinated-children-who-fall-ill-maybe-held-responsible/> accessed 25 July 2018.

39 Thestar.com.my, 'Vaccinate Kids or Face Jail, Parents Warned' (Nation The Star Online, 2018) <https://www.thestar.com.my/news/nation/2016/07/01/vaccinate-kids-or-face-jail-parentswarned-ministry-not-doing-so-akin-to-child-neglect> accessed 13 July 2018.

40 ibid.

${ }^{41}$ Thestar.com.my, 'Vaccines Free of Pork Gelatine' (Nation The Star Online, 2018) <http:// www.thestar.com.my/news/nation/2016/07/27/vaccines-free-of-pork-gelatine-specialist-stabiliserused-for-mmr-from-bovine-source/\#JxFdXT4soCcOy1dY.99> accessed 15 November 2017. 
only one vaccine that contains porcine DNA, which is the Rotavirus vaccine, and this vaccine is only available in private clinics to treat severe diarrhea, and not to be administered by the government hospitals. ${ }^{42} \mathrm{He}$ also advised Muslim parents to not believe the false information regarding the halal status of vaccines that has been circulated on the social media.

In Islamic perspective, vaccination is concerned directly with life and health and protection of the family and generation which relevant with the objectives (maqāṣid) of shariah namely Hifz al-deen (religion), Hifz al-nafs (life), Hifz al- 'aql (intellect), Hifz al-nasl (lineage) and Hifz al-mal (property) ${ }^{43}$ and upholds the spirit of al-wiqayah khairun min al-ilaj (prevention is better than cure). ${ }^{44}$ Islamic law aims to preserve essential and other interests by preserving their existence and also protecting them from destruction. This can be applied to the issue of vaccination where the well-being of the ummah must be protected from vaccines-preventable diseases as the outbreak of these diseases may destruct the harmony in a society.

The National Fatwa Committee of Malaysia (JAKIM) has issued Fatwas relating to the permissibility of vaccination. The Perlis Fatwa Committee has also decided that vaccination is obligatory for Muslims as it is proven that vaccination provides the most effective method in preventing diseases form spreading. ${ }^{45}$ Therefore, it is sinful for parents to refuse vaccinations for their children as this irresponsible decision can endanger the lives of their children. ${ }^{46}$ In addition, parents should realize that causing disease outbreak by preventing vaccinations is also sinful in the eyes of Islam. ${ }^{47}$

${ }^{42}$ Thestar.com.my, 'Health Ministry: Vaccines in Public Hospitals Guaranteed to Be Halal' (Nation The Star Online, 2018) <https://www.thestar.com.my/news/nation/2018/03/17/vaccines-inpublic-hospitals-guaranteed-to-be-halal/\#X0EuWRjWzJ0ftlo1.99> accessed 29 July 2018.

43 Abul Fadl Mohsin Ebrahim, 'VaCcination In The Context Of Al-Maqasid Al-Shari'Ah (Objectives Of Divine Law) And Islamic Medical Jurisprudence' (2014) 3 Arabian Journal of Business and Management Review (Oman Chapter) <https://www.arabianjbmr.com/pdfs/OM VOL_3_(10)/3.pdf $>$.[44].

${ }^{4}$ ibid.

45 Freemalaysiatoday.com, 'Vaccination Is Obligatory for Muslims, Says Perlis Fatwa' (Malaysia Today online, 2016) <http://www.freemalaysiatoday.com/category/nation/2016/11/12/ vaccination-is-obligatory-for-muslims-says-perlis-fatwa/> accessed 3 September 2018.

${ }^{46}$ ibid.

47 ibid. 
Syeikh Abdul Aziz bin Abdullah bin Baz, a Saudi Arabian Islamic scholar has remarked that vaccination with the purpose to curb the spread of contagious disease is highly encouraged ${ }^{48}$ He said that there is nothing wrong with giving treatment for the purpose of protection if there is the fear that the disease may occur because of the presence of an epidemic or other factors which may cause disease. ${ }^{49}$ In addition, the eminent Muslim scholar Sheikh Yusuf Al-Qaradawi states that the usage of vaccines in boosting immunity against disease is lawful as it is a means of warding off something evil before it afflicts people.

It should be noted that in the event where there is no cure except the one that contains forbidden substance, Islam grants permission on the basis of emergency (Dharurat).$^{50}$ This is based on Islamic jurisprudence method Al-Dharurat tubikhu al-Mahzhurat (Dharurat situations permits that which is forbidden). ${ }^{51}$ The European Fatwa Committee has come to a decision on the matter of existence of pig DNAs in vaccines where the usage of medicine that is medically beneficial and protects children from diseases, such as polio is allowed; especially if there is no other alternative and the effect of not using the medicine will lead to greater harm and detriment. In Islam, medication is deemed to be a necessity.

\section{Conclusion}

It is undeniable that vaccinations have prevented millions from deaths. Immunization does not protect only the individual who had received vaccinations, but it also protect the entire families, the community and the country too. Therefore it is indeed a confusion when there is a certain group of people, or to be specific,

${ }^{48}$ S. Ahmed,[et., al.], 'Resistance to Polio Vaccination in Some Muslim Communities and the Actual Islamic Perspectives-A Critical Review’ (2014) 7 Research Journal of Pharmacy and Technology.[494].

49 ibid.

${ }^{50}$ Noor Munirah Isa, 'Darurah (Necessity) and Its Application in Islamic Ethical Assessment of Medical Applications: A Review on Malaysian Fatwa.' (2016) 22 Science and engineering ethics $<$ https://link.springer.com/article/10.1007/s11948-015-9698-1>.[1319-1332].

${ }^{51}$ N. Numar, 'Jabatan Kemajuan Islam Malaysia - Kenyataan Media Ketua Pengarah Jakim Berkenaan Isu Penggunaan Vaksin’ (Islam.gov.my, 2018) < http://www.islam.gov.my/media-jakim/ kenyataan-media/596-isu-penggunaan-vaksin> accessed 14 November 2017. 
parents, who refused vaccinations for their children for reasons that are definitely of lower weight than deaths! To risk their own children's life is indeed incomprehensible. For that reason, it is seen crucial for the government to take measures in their hands now, id est to make things legal. It is hoped that the relevant authorities will take note that this is a serious issue that need to be addressed, one of the way is by enforcing legislation on vaccination. To follow the footsteps of the government of California is said to be of a wise decision. As the first step, Malaysian government can always refer to countries that have made vaccinations compulsory as per in this article, where reference is made to the California law. Sometimes people will succumb if they faced the consequences of being punished.

Compromising our children's health, the future generations is obviously not an option. Seeing the uprising trend of parents rejecting vaccination should put us more on guarded feet to not let any loopholes entertain them as this will jeopardize the herd immunity wanted by vaccination. It is submitted here that there is a critical need for the government to end the anti-vaccination movement, in order to prevent the vaccination preventable diseases from infecting children. This is because children have weaker immune system and thus most vulnerable to vaccine-preventable diseases. Seeing the need to curb the anti-vaccination movement, Malaysia may as well refer to the California vaccination law in planning for legislations to ensure better vaccination coverage, compromising no refusal from parents. Refusal from parents should only make them responsible to their own deliberate careless action and to decline unvaccinated children from entering day care, nursery, and public schools as being enforced in California at this moment. It is hoped that if this kind of action is enforced by the government, refusing parents will contemplate before immediately saying no to vaccination, as obviously, a decision that resulted in their children being rejected to enter get education is not an option. If these parents unbelievably still refuse, declining unvaccinated children to day care, nursery and public school will at least help in preventing vaccination preventable diseases from being communicated to other children in school. This ensure some kind of control mechanism to public health authorities in curbing the spreading of communicable 
diseases. However, besides making vaccination compulsory for children, it is also emphasized here that the public health authorities definitely has a great responsibility in educating parents about the importance of vaccination for the benefit of their own children and also the society.

\section{Bibliography}

Abul Fadl Mohsin Ebrahim, 'VaCcination In The Context Of Al-Maqasid AlShari'Ah (Objectives Of Divine Law) And Islamic Medical Jurisprudence' (2014) 3 Arabian Journal of Business and Management Review (Oman Chapter) $<$ https://www.arabianjbmr.com/pdfs/OM_VOL_3_(10)/3.pdf $>$.

Dorit Rubinstein Reiss, 'Vaccines, School Mandates, and California's Right to Education' (2015) 63 UCLA Law Review Discourse.

Faridah Kusnin, 'Immunisation Program in Malaysia', Vaccinology 2017 III International Symposium for Asia Pacific Experts (Health Physician Disease Control Division Ministry of Health, Malaysia 2017) $<$ https://www.fondationmerieux.org/wp-content/uploads/2017/10/vaccinology-2017-faridah-kusnin. pdf $>$.

Freemalaysiatoday.com, 'Vaccination Is Obligatory for Muslims, Says Perlis Fatwa' (Malaysia Today online, 2016) <http://www.freemalaysiatoday.com/ category/nation/2016/11/12/vaccination-is-obligatory-for-muslims-saysperlis-fatwa/> accessed 3 September 2018.

G. A Poland and R. M Jacobson, 'The Clinician's Guide to the Anti-Vaccinationists' Galaxy’ (2012) 73 Human immunology.

Jenifer Ehreth, 'The Global Value of Vaccination' (2003) 21 Vaccines $<$ https://www. researchgate.net/publication/10948246_The_global_value_of_vaccination>.

Kementerian Kesihatan Malaysia, 'Kementerian Kesihatan Malaysia' (Facebook. com, 2018) <https://www.facebook.com/kementeriankesihatanmalaysia/ photos/a.390879946236.176260.373560576236/10153207377521237/?type $=3 \&$ theater $>$ accessed 12 March 2018.

Leginfo.legislature.ca.gov, 'California Legislative Information' (Leginfo. legislature.ca.gov, 2018) <http://leginfo.legislature.ca.gov> accessed 14 November 2017.

M Chow, 'Anti-Vaccine Group's Actions at "worrying Level” among Malays' (Free Malaysia Today, 2018) <http://www.freemalaysiatoday.com/category/ nation/2018/03/27/anti-vaccine-groups-actions-at-worrying-level-among- 
malays/> accessed 12 July 2018.

Moh.gov.my., 'Official Portal for Ministry of Health MalaysiaFrequently Asked Questions' (Moh.gov.my., 2018) <http://www.moh.gov.my/english.php/ pages/view/160> accessed 25 July 2018.

Moh.gov.my, 'Official Portal for Ministry of Health MalaysiaPaediatric \& Child Health' (Moh.gov.my, 2018) < http://www.moh.gov.my/english.php/pages/ view/218> accessed 13 November 2017.

N. Numar, 'Jabatan Kemajuan Islam Malaysia - Kenyataan Media Ketua Pengarah Jakim Berkenaan Isu Penggunaan Vaksin' (Islam.gov.my, 2018) $<$ http://www. islam.gov.my/media-jakim/kenyataan-media/596-isu-penggunaan-vaksin> accessed 14 November 2017.

Noor Munirah Isa, 'Darurah (Necessity) and Its Application in Islamic Ethical Assessment of Medical Applications: A Review on Malaysian Fatwa.' (2016) 22 Science and engineering ethics $<$ https://link.springer.com/article/10.1007/ s11948-015-9698-1>.

Outbreak News Today, 'Malaysia: Diphtheria, Measles and Vaccination Rejection' (Outbreak News Today, 2018) <http://outbreaknewstoday.com/malaysiadiphtheria-measles-and-vaccination-rejection-52840/> accessed 20 June 2017.

S. Ahmed, [et.,al.], 'Resistance to Polio Vaccination in Some Muslim Communities and the Actual Islamic Perspectives-A Critical Review' (2014) 7 Research Journal of Pharmacy and Technology.

S. L. Plotkin and Stanlay A. Plotkin, 'A Short History of Vaccination' (2004) 5 Vaccines.

S Riedel, 'Edward Jenner and the History of Smallpox and Vaccination' (2005)

18 Baylor University. Medical Center <https://www.ncbi.nlm.nih.gov/ pubmed/16200144>.

Thestar.com.my, 'Health Ministry: Five Deaths Due to Diphtheria Recorded' (The Star Online, 2018) <https://www.thestar.com.my/news/nation/2016/06/30/ health-ministry-diphtheria-deaths/> accessed 25 July 2018.

— - 'Health Ministry: Vaccines in Public Hospitals Guaranteed to Be Halal' (Nation The Star Online, 2018) <https://www.thestar.com.my/news/ nation/2018/03/17/vaccines-in-public-hospitals-guaranteed-to-behalal/\#X0EuWRjWzJ0ftlo1.99> accessed 29 July 2018. 
_- 'Parents of Unvaccinated Children Who Fall Ill May Be Held Responsible' (Nation The Star OnlineThe Star Online, 2018) <http://www.thestar. com.my/news/nation/2016/08/29/perak-tackles-vaccine-issue-parents-ofunvaccinated-children-who-fall-ill-may-be-held-responsible/ $>$ accessed 25 July 2018.

—_ 'Vaccinate Kids or Face Jail, Parents Warned' (Nation The Star Online, $2018)<$ https://www.thestar.com.my/news/nation/2016/07/01/vaccinate-kidsor-face-jail-parents-warned-ministry-not-doing-so-akin-to-child-neglect> accessed 13 July 2018.

—, 'Vaccines Free of Pork Gelatine' (Nation The Star Online, 2018) $<$ http://www.thestar.com.my/news/nation/2016/07/27/vaccines-freeof-pork-gelatine-specialist-stabiliser-used-for-mmr-from-bovinesource/\#JxFdXT4soCcOyldY.99> accessed 15 November 2017.

Varun K. Phadke, 'Association between Vaccine Refusal and Vaccine-Preventable Diseases in the United States: A Review of Measles and Pertussis' (2016) 315. JAMA < https://jamanetwork.com/journals/jama/article-abstract/2503179>

Y. Toni Yang, [et.,al.] 'Measles Outbreak as a Catalyst for Stricter Vaccine Exemption Legislation’ (2015) 314 JAMA <https://jamanetwork.com/journals/jama/ article-abstract/2417307>.

HOW TO CITE: Nurul Jannah binti Mustafa Khan and Zuhaira Nadiah binti Zulkipli, 'Compulsory Vaccination for Children in Malaysia: Legislation and Realisation' (2018) 33 Yuridika. 